Article

\title{
Intermetallic Phases in High-Entropy Alloys: Statistical Analysis of their Prevalence and Structural Inheritance
}

\author{
Ming-Hung Tsai ${ }^{1,2, *}$, Ruei-Chi Tsai ${ }^{1}$, Ting Chang ${ }^{1}$ and Wen-Fei Huang ${ }^{1}$ \\ 1 Department of Materials Science and Engineering, National Chung Hsing University, Taichung 402, Taiwan; \\ trc19930408@gmail.com (R.C.T.); ace1123581321@gmail.com (T.C.); iamsophiahere@gmail.com (W.F.H.) \\ 2 High Entropy Materials Center, National Tsing Hua University, Hsinchu 30013, Taiwan \\ * Correspondence: mhtsai@nchu.edu.tw; Tel.: +886-4-2285-1243
}

Received: 20 January 2019; Accepted: 16 February 2019; Published: 19 February 2019

\begin{abstract}
Strengthening high entropy alloys (HEAs) via second phases is a very effective approach. However, the design of intermetallic (IM) phases in HEAs is challenging, mainly because our understanding of IM phases in HEAs is still very limited. Here, a statistical approach is used to enhance our understanding towards IM phases in HEAs. A database consisting of 142 IM-containing HEAs was constructed. Our aim is twofold. The first is to reveal the most common IM phase types in published HEAs. The second is to understand whether HEAs inherit their IM structures from their binary/ternary subsystems, or whether they tend to form new structures irrelevant to their subsystems. The results show that the five most prevalent IM structures in the HEAs surveyed here are Laves, $\sigma, \mathrm{B} 2, \mathrm{~L}_{2}$, and $\mathrm{L} 2{ }_{1}$. This trend is evidently different from the overall trend among known binary/ternary IMs. As for structural inheritance, all the IM phases contained in the alloys are existing structures in the binary/ternary subsystems of the respective alloys. This suggests that the compositional complexity in HEAs does trigger additional complexity in IM structure formation. These findings have important implications in the future design and development of HEAs.
\end{abstract}

Keywords: high-entropy alloys; intermetallic; alloy design; phase stability

\section{Introduction}

High-entropy alloys (HEAs) have attracted significant attention in the past decade [1-3]. The formation of simple solid solutions (SSSs) in these complex alloys is unexpected and intriguing. Thus, a lot of effort in the HEA community has been devoted to the design and physical metallurgy of SSS HEAs [4-11]. Studies have shown that these alloys do have unusual properties [12-16]. However, their room temperature mechanical properties are often not as pleasing. In particular, the strengths of FCC alloys are often insufficient [17,18].

A very effective approach for strengthening alloys is the incorporation of second phases. Therefore, recently, some researchers proposed that instead of focusing on SSS alloys, more attention should be paid to HEAs that contain intermetallic (IM) phases $[2,19,20]$. In fact, incorporating second phases was even considered one of the three key strategies for the future development of HEAs [21]. Indeed, experimental results have shown that IM phases can improve the mechanical properties of HEAs. For example, the outstanding wear resistances in the $\mathrm{Al}_{0.2} \mathrm{Co}_{1.5} \mathrm{CrFeNi}_{1.5} \mathrm{Ti}$ and $\mathrm{Al}_{0.3} \mathrm{CrFe}_{1.5} \mathrm{MnNi}_{0.5}$ alloys are the results of the formation of $\eta$ and $\sigma$ phases, respectively [22,23]. Very recently, it has been demonstrated that through carefully designed second phases, high strength and good ductility can even be achieved simultaneously [24-27]. For instance, the ( $\mathrm{FeCoNiCr})_{94} \mathrm{Ti}_{2} \mathrm{Al}_{4}$ alloy shows a yield strength of over $1 \mathrm{GPa}$, while keeping a high tensile ductility of $17 \%$. This is due to the engineering of $\gamma^{\prime}$ precipitates through various thermomechanical processes [24]. 
However, the tailoring of IM phases in HEAs for property enhancement is still very challenging. This is because compared with SSS phases; our fundamental understanding of IM phases in HEAs is still very limited. For example, there have been more than 20 publications regarding the formation criterion and stability of SSS phases in HEAs [6,28-31], although some of the earlier works have limited accuracy due to imprecise experimental data. In contrast, papers discussing IM phases in HEAs are very rare. Currently there are only one criterion on the general selection of IM phase type [32], and three stability criterions on two specific IM phase types ( $\sigma$ and Laves phases) [33-35].

To predict the stability of IM phases in HEAs, the reasonable first step is to identify the types of phases that could form in the alloy, and then compare the relative stabilities of these candidates. However, even the first step is difficult. Unlike the case in SSS phases, where only three types of structures are concerned (FCC, BCC, and HCP), there are more than two thousand structure types for IM phases [36]. A plausible assumption is that the candidate IM phases in HEAs are the IM phases in their subsystems (for quinary HEAs this means all quaternary, ternary, and binary subsystems). This is similar to the case in many ternary systems, where the IM phases are all inherited from the three binary subsystems. Nevertheless, even in ternary alloys this assumption is not necessarily true (i.e., there could be new structures that do not exist in the three binary subsystems). In HEAs, the composition is apparently more complex, which renders the above assumption even more questionable. In addition, in HEAs a new class of IM phases called high entropy intermetallics (HEI) have been reported [21]. These new IM phases show completely new compositions that have not reported before, which further complicates the determination of the candidate IM phases.

This work is the first part of an attempt to understand the IM phases in HEAs from a macroscopic viewpoint. A database of 142 IM-containing HEAs is constructed. Care is taken to reduce alloys with similar composition so that the diversity in the database is enhanced. The alloys and their respective IM structures are statistically analyzed. Our goal is twofold. The first is to reveal the most common IM phase types in HEAs. The results in HEAs are then compared with the general trends in binary and ternary IM phases and discussed. The second is to understand the inheritance of IM structures in HEAs. The IM structure types in the HEAs are compared with those in their subsystems to see if the structures are inherited from the subsystems of the alloys. The frequency which irrelevant (i.e., not existing in corresponding subsystems) structure types occur is also probed and discussed.

\section{Construction of the Alloy Database}

The HEAs in this research were collected using the following principles:

(1) Only alloys that contain IM phases were collected because our target is the IM phases.

(2) Alloys that have unidentified or uncertain IM phase types were excluded. In other words, either the formula (e.g., $\mathrm{Fe}_{2} \mathrm{Ti}$ ) or the common/trivial name (e.g., $\sigma$ ) of all the compounds in the alloy has to be reported. This is because including these alloys leads to difficulty in our analysis.

(3) Alloys with similar composition and identical IM phase constituents were listed only once (i.e., only one of the alloys was included). Two alloys are considered to have similar compositions if they have the same composing elements, and only the relative concentrations of the elements are different. This is because many studies fabricate series of alloys by systematically changing the content of a particular element. For example, He et al. [37] conducted detailed study on the effect of $\mathrm{Al}$ on the structure and properties of $\mathrm{Al}_{\mathrm{x}} \mathrm{CoCrFeMnNi}$ alloys. They fabricated a total of 14 alloys $(x=0.02$, $0.03,0.04,0.08,0.09,0.1,0.11,0.12,0.14,0.15,0.16,0.18,0.19$, and 0.25$)$. Ten of the 14 alloys have the same IM phase constituent: B2. This similarity is not surprising; the alloys are composed of the same elements and the relative concentrations of these elements do not change significantly. If these alloys are all included, they and the IM phase they contain will have an unreasonably high weighting in the database, which will lead to biased results in subsequent analyses. Therefore, only one of the ten alloys was included in the database.

(4) If the same alloy contains different IM phases under different processing conditions, each condition with different IM phase constituents will be recorded separately. 
However, in subsequent analyses these phases will be combined into one entry and counted only once. Assume the phase constituent of an alloy in the as-cast, $1100{ }^{\circ} \mathrm{C}$ annealed, and $900{ }^{\circ} \mathrm{C}$ annealed states are $(\alpha, \beta),(\alpha, \beta, \gamma)$, and $(\alpha, \delta)$, respectively. These three states will all be recorded in the database. However, when calculating, for example, the number of occurrences for each IM phase, the three records will be combined. The alloy will be regarded as containing four phases $(\alpha, \beta, \gamma$, and $\delta)$ and counted only once.

Based on the above principles, a total of 142 IM-containing HEAs with sufficient compositional distinction are collected. These principles enhance the diversity of our database, and can markedly reduce the bias from compositional repetition. As an example, Miracle and Senkov published a comprehensive review on HEAs recently [3]. In their review, an HEA database with a total of 408 unique alloys was constructed. 247 of the 408 alloys contain IM phases. However, using the above principles, only 74 of the 247 alloys $(\sim 30 \%)$ will be included our database $-70 \%$ of the alloys are excluded because of compositional similarity. This clearly shows the efficacy of the above principles.

\section{Results and Discussion}

\subsection{Characterization of the Database}

Table 1 shows the alloy database constructed in this research. It lists the composition, processing condition, and the solid solution and IM phases of each alloy. The abbreviations used in Table 1 are explained in the footnote of the table. Because the target of this research is the IM phase, each IM phase in the alloy is listed in a separate row. Three types of structure information are recorded (if possible). The first is the phase name. This is the common name for each structure (if it exists). Common name are either based on Strukturbericht notation or common trivial names [38] for certain structure types (most notably the topologically closed packed phases). For example, B2 is the Strukturbericht notation for $\mathrm{CP} 2-\mathrm{CsCl}$ and $\sigma$ is the trivial name for $\mathrm{tP} 30-\mathrm{CrFe}$. The second is the compound name reported in the original work (if reported). The third is the structure prototype of the phase. In many cases, the original publication only reports the common name of the phase without indicating the exact compound. In such cases the "compound reported" column will be left empty. Contrarily, if only the compound is reported, the common name of the phase will be identified based on the structure prototype. Moreover, to probe the structural inheritance in the alloys, the binary and ternary subsystems of each alloy are examined using various handbooks [39-41] to see whether the observed IM phases already exist in the subsystems. Binary subsystems are examined first. If the target IM phase can be found in any of the binary subsystems, the search is stopped and the subsystem will be recorded in the "IM Structure Found in" column. If the IM phase does not exist in any binary subsystem, the search will be continued in ternary ones and then recorded (if found). It should be noted that one IM phase can often be found in multiple subsystems. However, due to space limit only one of the subsystems is recorded. 
Table 1. Composition, processing condition, phase constituents, and structural inheritance of the 142 IM-containing HEAs considered in this study.

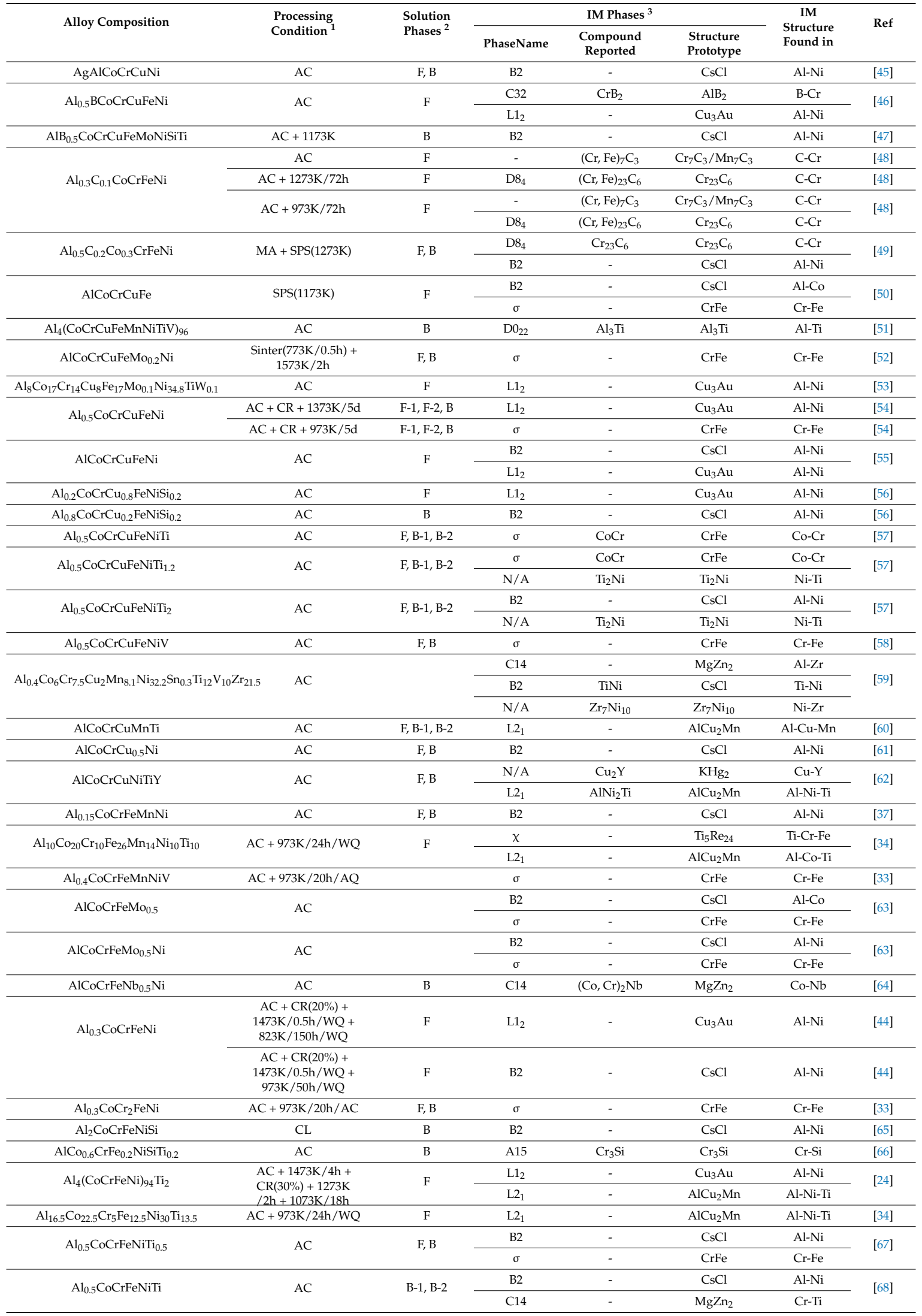


Table 1. Cont.

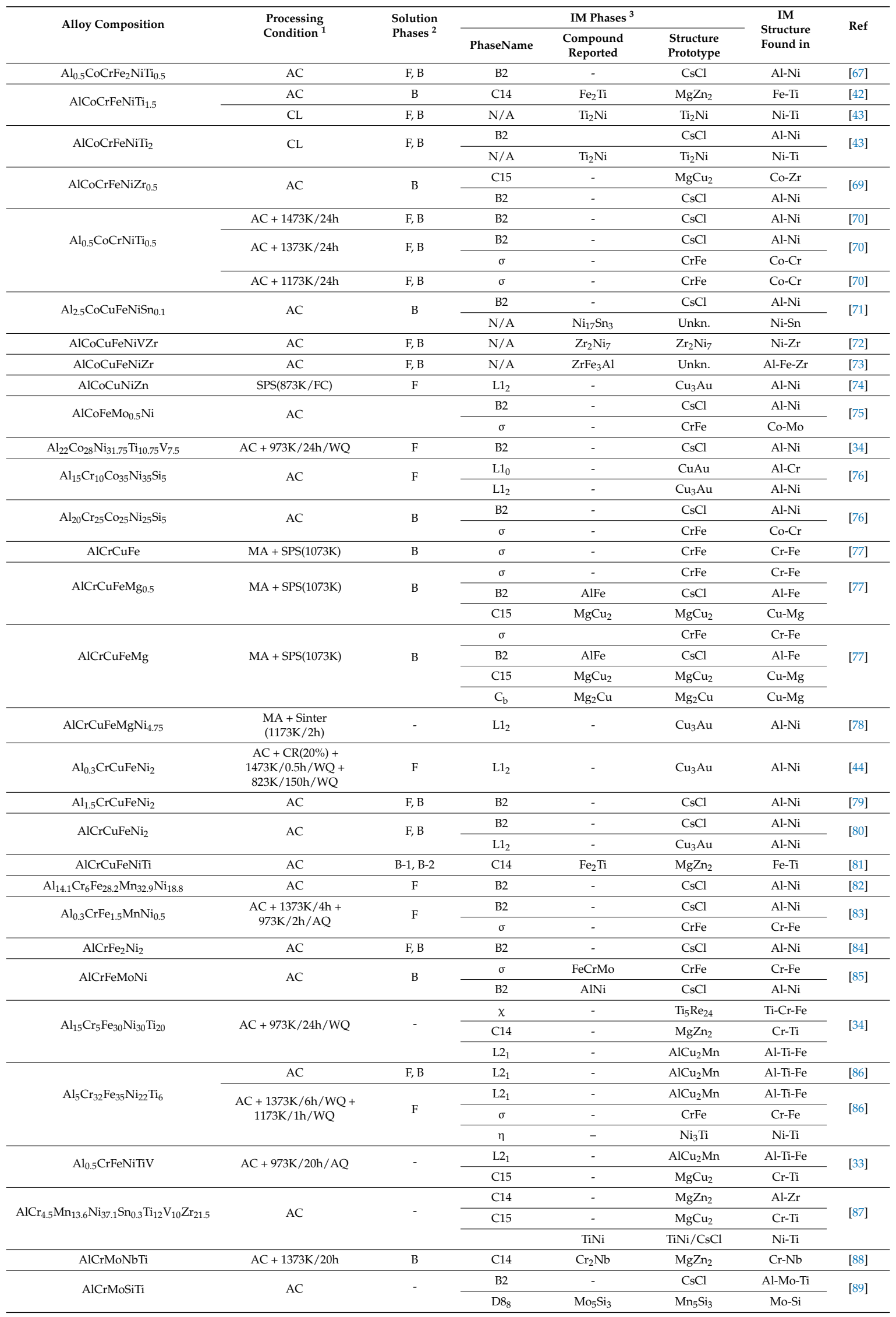


Table 1. Cont.

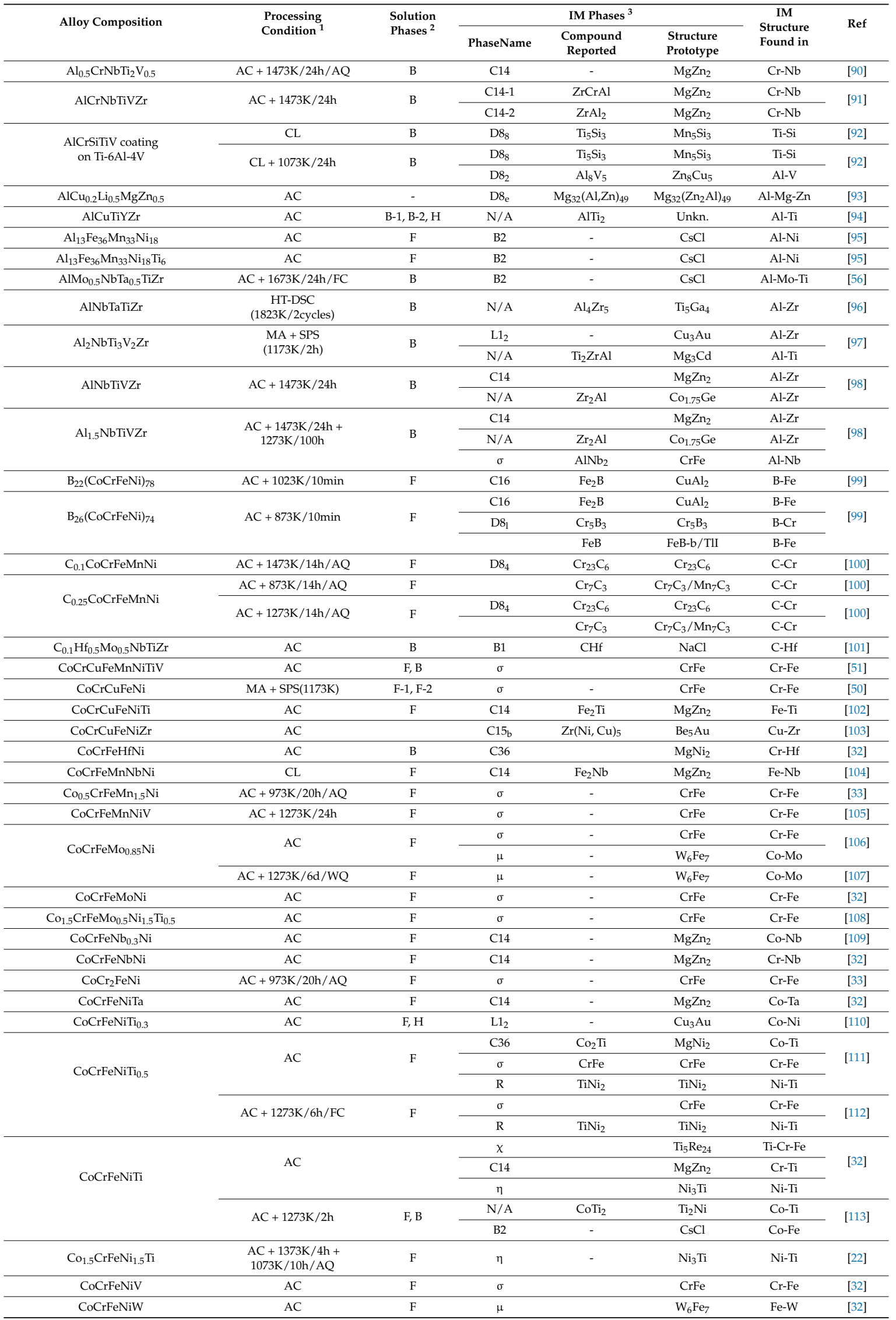


Table 1. Cont.

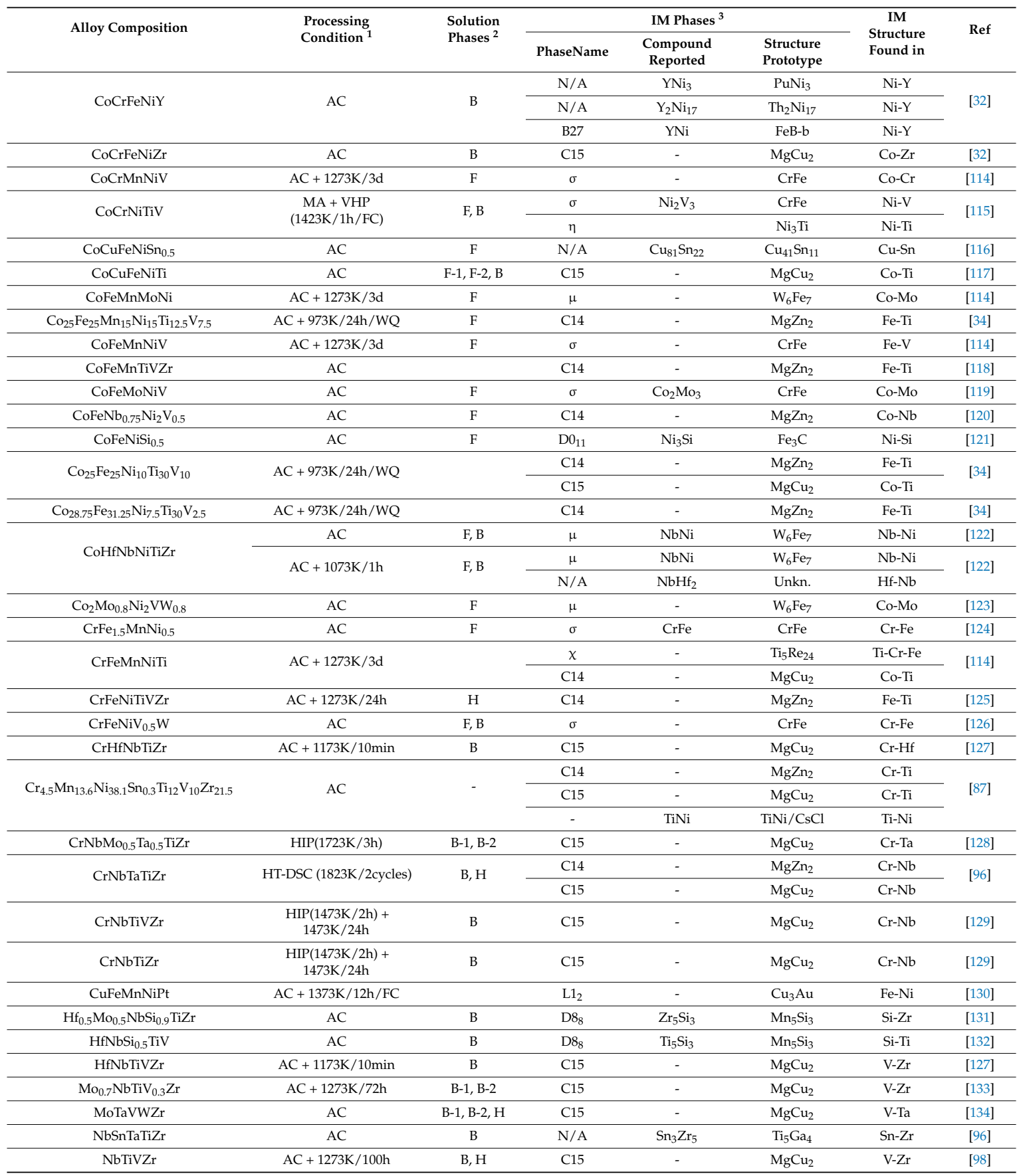

${ }^{1}$ The abbreviations used for processing conditions are: AC = As-Cast; MA = Mechanical Alloyed; SPS = Spark Plasma Sintered; $\mathrm{CR}=$ Cold Rolled; $\mathrm{WQ}=$ Water Quenched; $\mathrm{AQ}=$ Air Quenched; $\mathrm{CL}=$ Cladded; $\mathrm{FC}=$ Furnace Cooled; HT-DSC = High Temperature-Differential Scanning Calorimeter; VHP = Vacuum Hot Press; HIP = Hot Isostatic Pressing. ${ }^{2}$ The abbreviations used for SSS phases are: $\mathrm{F}=\mathrm{FCC} ; \mathrm{B}=\mathrm{BCC} ; \mathrm{H}=\mathrm{HCP}$. When there is more than one FCC or BCC phases, a number will be added after the abbreviation. For example, F-1 and F- 2 . ${ }^{3}$ The abbreviations for IM structures are: $\mathrm{A} 15=\mathrm{cP} 8-\mathrm{Cr}_{3} \mathrm{Si}$; $\mathrm{B} 1=\mathrm{cF} 8-\mathrm{NaCl} ; \mathrm{B} 2=\mathrm{cP} 2-\mathrm{ClCs} ; \mathrm{B} 27=\mathrm{oP} 8-\mathrm{FeB}-\mathrm{b}$; $\mathrm{C} 14=\mathrm{hP} 12-\mathrm{MgZn} 2 ; \mathrm{C} 15=\mathrm{cF} 24-\mathrm{Cu}_{2} \mathrm{Mg} ; \mathrm{C} 15 \mathrm{~b}=\mathrm{cF} 24-\mathrm{Be}_{5} \mathrm{Au} ; \mathrm{C} 16=\mathrm{t} 12-\mathrm{Al}_{2} \mathrm{Cu} ; \mathrm{C} 32=\mathrm{hP3}-\mathrm{AlB}_{2} ; \mathrm{C} 36=\mathrm{hP} 24-\mathrm{MgNi}_{2} ;$ $\mathrm{Cb}=$ oF48- $\mathrm{Mg}_{2} \mathrm{Cu}, \mathrm{D} 0_{11}=$ oP16-Fe 3 C, D0 $22=\mathrm{tI} 8-\mathrm{Al}_{3} \mathrm{Ti} ; \mathrm{D} 8_{2}=\mathrm{cI} 52-\mathrm{Cu}_{5} \mathrm{Zn}_{8} ; \mathrm{D} 8_{4}=\mathrm{cF} 116-\mathrm{Cr}_{23} \mathrm{C}_{6} ; \mathrm{D} 8{ }_{8}=\mathrm{hP16}-\mathrm{Mn}_{5} \mathrm{Si}_{3} ;$ $\mathrm{D} 8 \mathrm{e}_{\mathrm{e}}=\mathrm{cI} 162-\mathrm{Mg}_{32}\left(\mathrm{Zn}_{2} \mathrm{Al}\right)_{49} ; \mathrm{D} 8 \mathrm{I}=\mathrm{tI} 325-\mathrm{Cr}_{5} \mathrm{~B}_{3} ; \eta=\mathrm{hP16}-\mathrm{TiNi}_{3} ; \mathrm{L} 2_{1}=\mathrm{cF} 16-\mathrm{AlCu}_{2} \mathrm{Mn}, \chi=\mathrm{cI} 58-\mathrm{Ti}_{3} \mathrm{Re}_{24}$ $\mathrm{L}_{0}=\mathrm{tP} 2-\mathrm{AuCu} ; \mathrm{L}_{2}=\mathrm{cP} 24-\mathrm{AuCu}_{3} ; \mu=\mathrm{hR} 13-\mathrm{Fe}_{7} \mathrm{~W}_{6} ; \mathrm{R}=\mathrm{hR} 21-\mathrm{TiNi}_{2} ; \sigma=\mathrm{tP} 30-\mathrm{CrFe}$. Some reported compounds have two different structures, both structures are listed and separated with a slash. For such compounds, "phase name" will be left empty. In addition, structure prototypes of certain compounds are yet unknown. This is abbreviated as Unkn. 
The 142 IM-containing alloys use a total of 25 elements. This includes 1 alkali metal (Li); 1 alkaline earth metal (Mg); 18 transition metals $(\mathrm{Ag}, \mathrm{Co}, \mathrm{Cr}, \mathrm{Cu}, \mathrm{Fe}, \mathrm{Hf}, \mathrm{Mn}, \mathrm{Mo}, \mathrm{Nb}, \mathrm{Ni}, \mathrm{Pt}, \mathrm{Ta}, \mathrm{Ti}, \mathrm{V}, \mathrm{W}, \mathrm{Y}$, $\mathrm{Zn}, \mathrm{Zr}$ ); 2 basic metals (Al, Sn); 2 metalloids (B, Si) and 1 non-metal (C). To understand the prevalence of these elements in our alloy database, the relative frequency of usage of each element is calculated and plotted in Figure 1. Co, Cr, Fe, and Ni are the most common elements in this study and have relative frequencies higher than $66 \%$. $\mathrm{Al}(56 \%)$ and $\mathrm{Ti}(49 \%)$ also have very high relative frequencies. Three other elements, including $\mathrm{Cu}(28 \%), \mathrm{V}(25 \%)$, and $\mathrm{Zr}(21 \%)$, have relative frequencies higher than $20 \%$. All other elements have relative frequencies below $20 \%$.

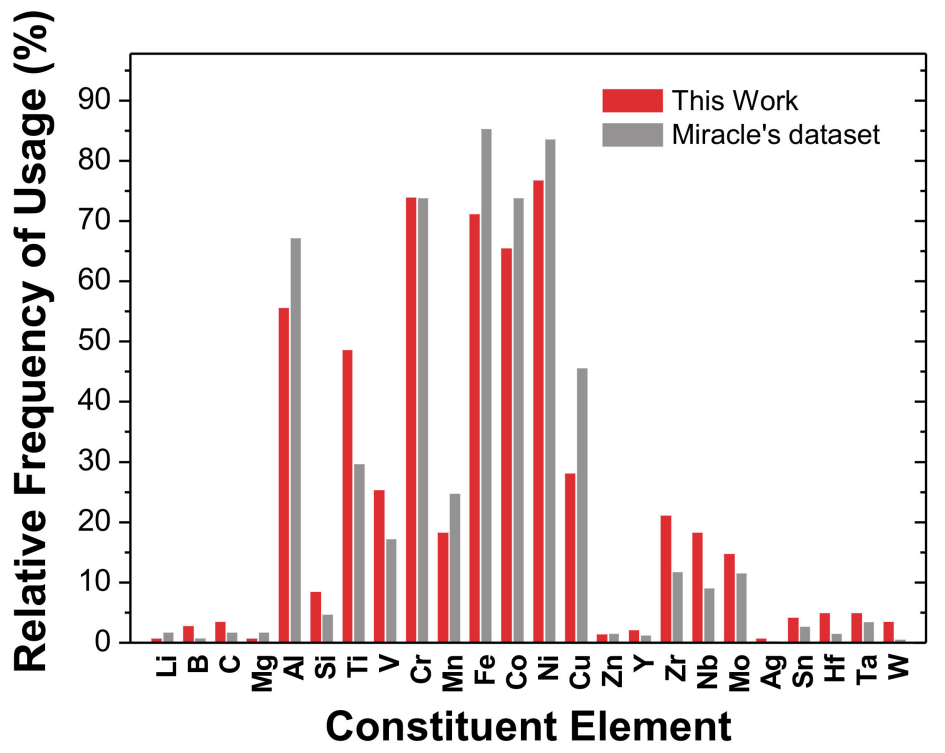

Figure 1. Relative frequencies of usage of various elements in the present study and in Miracle and Senkov's work, data from [3].

Miracle and Senkov published a comprehensive review on HEAs very recently [3]. They constructed an HEA database with a total of 408 unique alloys, regardless of the phase type present in the alloy. Thus, their alloys can serve as a good comparison group to ours. The frequency with which each element is used in their database has been calculated [3]. This data is converted to relative frequency and plotted in Figure 1. As seen in Figure 1, $\mathrm{Co}, \mathrm{Cr}, \mathrm{Fe}$, and Ni still have the highest relative frequencies ( $74 \%$ or higher). Other elements having relative frequencies higher than $20 \%$ include $\mathrm{Al}(67 \%), \mathrm{Cu}(46 \%), \mathrm{Ti}(30 \%)$, and $\mathrm{Mn}(25 \%)$. Therefore, the seven most common elements in both databases are the same, but the relative sequence is slightly different. The popularity of these elements in both databases is largely because most of them belong to the two classic HEA systems [2]: $\mathrm{Al}-\mathrm{Co}-\mathrm{Cu}-\mathrm{Cr}-\mathrm{Fe}-\mathrm{Ni}$ and $\mathrm{Al}-\mathrm{Co}-\mathrm{Cr}-\mathrm{Fe}-\mathrm{Ni}$. These systems and their derivative systems (systems having two or fewer different principal elements) constitute the largest HEA family [2,3]. Thus, the popularity of these elements is not unexpected.

Comparing the relative frequencies of the same element in the two databases also helps to reveal the differences between the two databases. Based on Figure 1, only six elements have lower relative frequencies in our database than in Miracle and Senkov's, namely $\mathrm{Al}, \mathrm{Fe}, \mathrm{Co}, \mathrm{Ni}, \mathrm{Cu}$, and $\mathrm{Mn}$. Other elements all have higher relative frequencies of usage in our database than in Miracle's. The reason for the former is two-fold. Firstly, in our database, alloys with similar compositions and identical phase constituents are only listed once (see Section 2). Many alloys containing $\mathrm{Al}, \mathrm{Fe}$, $\mathrm{Co}, \mathrm{Ni}, \mathrm{Cu}$, and $\mathrm{Mn}$ are thus excluded, leading to lower relative frequencies. For example, Miracle and Senkov's database lists 29 IM-containing alloys in the Al-Co-Cr-Cu-Fe-Ni system, but ours lists only two. The second is that many simple solid solution alloys are also composed of these elements. They are also excluded in the present study. The reason for the latter is evident-the majority of 
elements typically lead to the formation of IM phases. Thus, in a database of IM-containing alloys, they exhibit higher relative frequencies.

The alloys in our database can be roughly categorized into three groups. The first is the CoCrFeNi-based alloys. These are defined here as alloys containing more than 60 at. $\%$ of $\mathrm{Co}, \mathrm{Cr}$, $\mathrm{Fe}$, and Ni. The second is the refractory alloys, defined here as alloys containing more that 60 at. $\%$ of refractory elements ( $\mathrm{Cr}, \mathrm{Hf}, \mathrm{Mo}, \mathrm{Nb}, \mathrm{Ta}, \mathrm{Ti}, \mathrm{V}, \mathrm{W}$, and $\mathrm{Zr}$ ). The third is other alloys, which includes all alloys that do not belong to the previous groups. In our database, there are $86 \mathrm{CoCrFeNi}$-based alloys $(60.6 \%), 25$ refractory alloys $(17.6 \%)$, and 31 other alloys $(21.8 \%)$.

It is also worth noting that processing route can have an evident effect on the type of IM phase present in the alloys. For example, the IM phases in arc-melted [42] and cladded $\mathrm{AlCoCrFeNiTi}_{1.5}$ [43] alloys are different. Another example is the $\mathrm{Al}_{0.3} \mathrm{CoCrFeNi}$ alloy [44], in which different annealing temperature can lead to completely different IM phase type, and thus different mechanical properties.

\subsection{The Most Prevalent IM Structures}

Figure 2a shows the relative frequencies of occurrence for the most common IM structures in the present study. The sequence, in order of decreasing prevalence, is (values in parentheses indicate number of occurrence): Laves (44), $\sigma$ (38), B2 (37), $\mathrm{L}_{2}(15), \mathrm{L}_{1}(8), \mu(5), \mathrm{Ti}_{2} \mathrm{Ni}(5), \mathrm{D}_{4}(4)$, $\chi(4), \eta(4)$, and $D 8_{8}(4)$. The Laves phase includes three closely related structure types: C14, C15 and C36. Their respective values are indicated in the corresponding bars. From Figure 2a, Laves, $\sigma, \mathrm{B} 2, \mathrm{~L} 1_{2}$ and $\mathrm{L} 2{ }_{1}$ are the five most prevalent structures, with Laves, $\sigma$, and B2 appearing in more than $25 \%$ of the alloys. $\mathrm{L}_{2}$ and $\mathrm{L} 21_{1}$, on the other hand, appear in approximately $5-10 \%$ of the alloys. All other structures have relative frequencies lower than $5 \%$. In other words, the popularity of the structures is quite non-uniform. This is not unexpected because among all identified IM structure types, the distribution of popularity is also quite non-uniform. For example, about $50 \%$ of all known IM compounds belong to 44 most popular structure types [38] - that is less than $2 \%$ of the known structure types! Additionally, as shown in Figure 1, the usage of the elements in our HEAs is also quite non-uniform. This will further concentrate the structure of the IM phases to certain structure types because of compositional similarity.
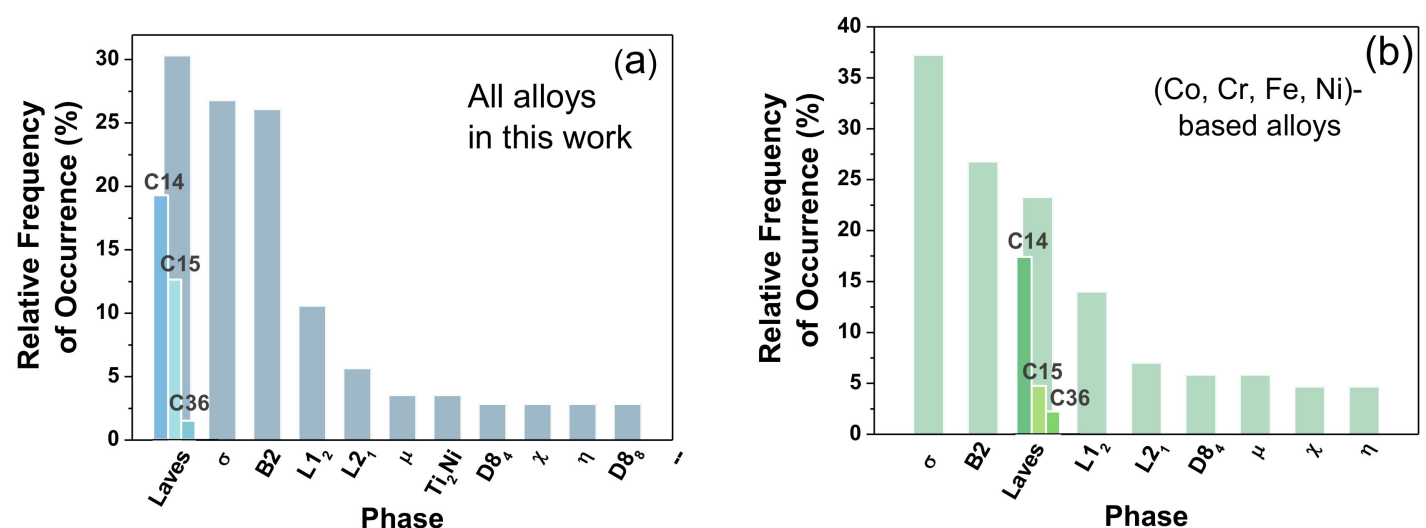

Figure 2. Relative frequencies of occurrence for the most common IM structures in this study: (a) Based on all alloys in the database; (b) Based on ( $\mathrm{Co}, \mathrm{Cr}, \mathrm{Fe}, \mathrm{Ni}$ )-based alloys only.

As mentioned previously, it is meaningful to compare the results of the present database and Miracle and Senkov's. Therefore, the relative frequencies of common IM structures in their alloy database are also calculated and plotted in Figure 3a. The most common IM structures in order of decreasing prevalence are (values in parentheses indicate number of occurrence): B2 (177), $\sigma(60)$, Laves (58) [C14 (50), C15 (8)], $\mathrm{L}_{2}$ (15), $\mathrm{E}_{3}(6), \mathrm{Ti}_{2} \mathrm{Ni}(5), \mathrm{D}_{2}$ (4), and $\mathrm{L} 2_{1}(4)$. Thus, the top four most common structures in the two databases are the same, but the relative sequence is different. This difference largely originates from the exclusion of compositionally similar alloys 
in the present study. For examples, there are a total of 334 IM-containing microstructure reports in Miracle and Senkov's study. However, the Al-Co-Cr-Fe-Ni alloy system alone accounts for 86 (or $25.7 \%$ ) of them! This is because Al-Co-Cr-Fe-Ni is one of the two "classic" systems that have been studied most thoroughly. Thus, the effect of composition has been probed in considerable detail. For instance, $\mathrm{Al}_{x} \mathrm{CoCrFeNi}$ alloys with $x=0.3,0.44,0.7,0.75,0.8,0.876,0.9,1,1.2,1.25,1.5,1.8,2,2.08$, 2.5 and 3 have all been reported. Besides composition, the effect of processing route is also probed, leading to even more microstructure reports. Unfortunately, the IM phases in the Al-Co-Cr-Fe-Ni system are very similar- 46 of them contain B2. Due to these reasons, the frequency of the B2 phase is evidently overestimated. This probably explains why B2 tops the list in Miracle and Senkov's database. Although their work is comprehensive and of great value, we believe our analysis better represents the overall reality by reducing the bias from similar alloys.
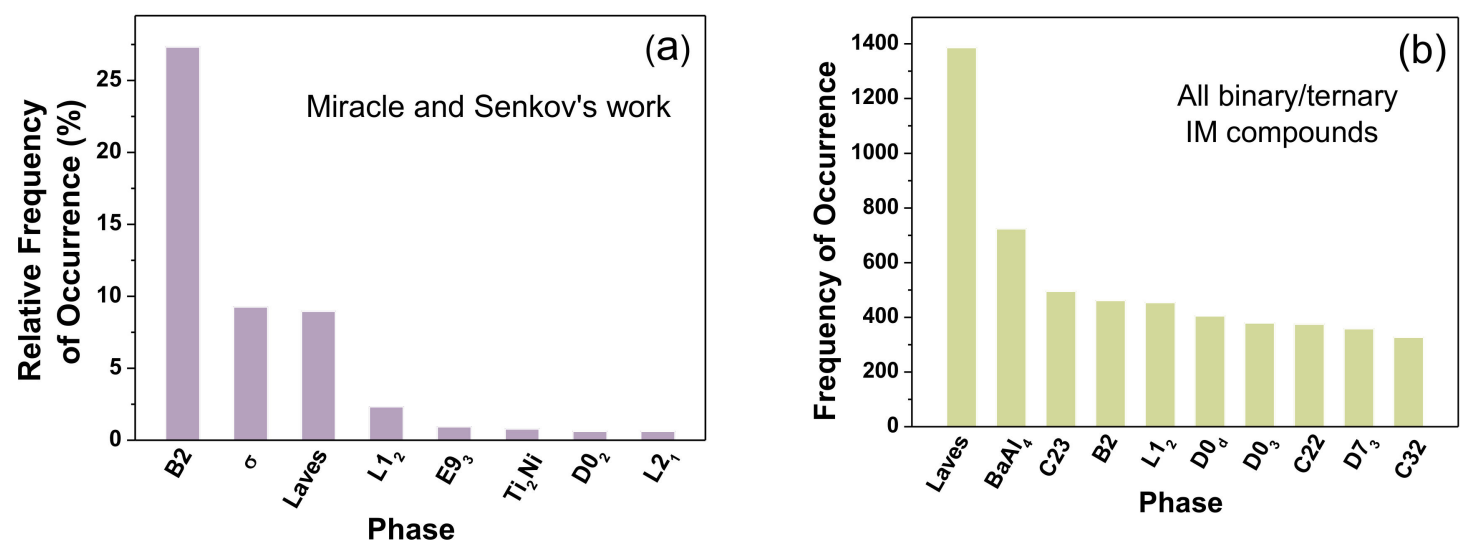

Figure 3. (a) Relative frequencies of occurrence for the most common IM structures in Miracle and Senkov's work, data from [3]; (b) Frequency of occurrence for the most common IM structures in all binary/ternary IM phases, data from [38].

Ferro and Saccone [38] calculated the most common structure types based on Villars and Calver's collection of about 26,000 known IM phases [36]. It is meaningful to compare our results with this over trend in all IM phases. Figure $3 \mathrm{~b}$ shows the most common structure types among all binary and ternary IM phases [38]. Please note that the $\mathrm{NaCl}$ structure is omitted in Figure $3 \mathrm{~b}$ because it is typically associated with non-metallic elements such as $\mathrm{O}$ and $\mathrm{N}$ (i.e., mostly ceramic phases). The five most common structures in order of decreasing prevalence are: Laves (including both $\mathrm{C} 14$ and $\mathrm{C} 15$ structures), $\mathrm{BaAl}_{4}, \mathrm{C} 23, \mathrm{~B} 2$, and $\mathrm{L}_{2}$. Compared with the top-five list in our database, it is seen that the Laves, $\mathrm{B} 2$, and $\mathrm{L}_{2}$ phases remain popular in $\mathrm{HEAs}$, but the $\mathrm{BaAl}_{4}$ and $\mathrm{Co}_{2} \mathrm{Si}$ structures do not appear in our HEA database at all. This distinction is not difficult to understand if we take a closer look at compounds with these structures. $\mathrm{BaAl}_{4}$-type compounds almost always contain elements in the lanthanide and actinide series, which are still very rarely used in HEAs [36]. The case for the C23 structure is similar-C23-type compounds are typically formed in compounds containing lanthanide, IIA, and IVA elements [36]. As will be shown later, IM structures formed in HEAs are always structures that existing in their subsystems. Consequently, if the necessary component of a particular structure is absent in an alloy, it is unlikely that such structure will form. By and large, the differences between the common IM structures in the present study and that in all binary/ternary IM compounds is probably because the explored compositional space in HEAs is still extremely limited.

For the (Co, $\mathrm{Cr}, \mathrm{Fe}, \mathrm{Ni}$ )-based alloys, the five most common phases (Figure $2 \mathrm{~b}$ ) listed in order of decreasing prevalence are: $\sigma$ (32), B2 (23), Laves (20), $\mathrm{L}_{2}$ (12), and $\mathrm{L} 2_{1}(6)$. The common phases are same as that in all alloys, but the relative popularity is different. This again suggests that the IM phases present are still dependent on the composition. As will be shown later, the IM phases in HEAs are basically the IM phases that already exist in its binary and/or ternary subsystems. Thus, the choice of element is directly related to the type of IM phase. 


\subsection{Structure Inheritance in HEAs}

Before going further, it is useful here to explain the term "structural inheritance" using ternary systems as examples. IM phases in ternary phase diagrams are very often extended from the boundary of the diagrams. In other words, they are often solid solutions of binary IM phases. Thus, the IM structure already exists in at least one of the three binary subsystems. In this work, this is described as the inheritance of the IM structure in the ternary alloy from its binary subsystems. In some cases, the IM phase region can even connect from one edge of the triangle to another, as illustrated in the imaginary phase diagram in Figure 4a. Similarly, in a quaternary system, the IM structures can be inherited from binary and ternary subsystems.
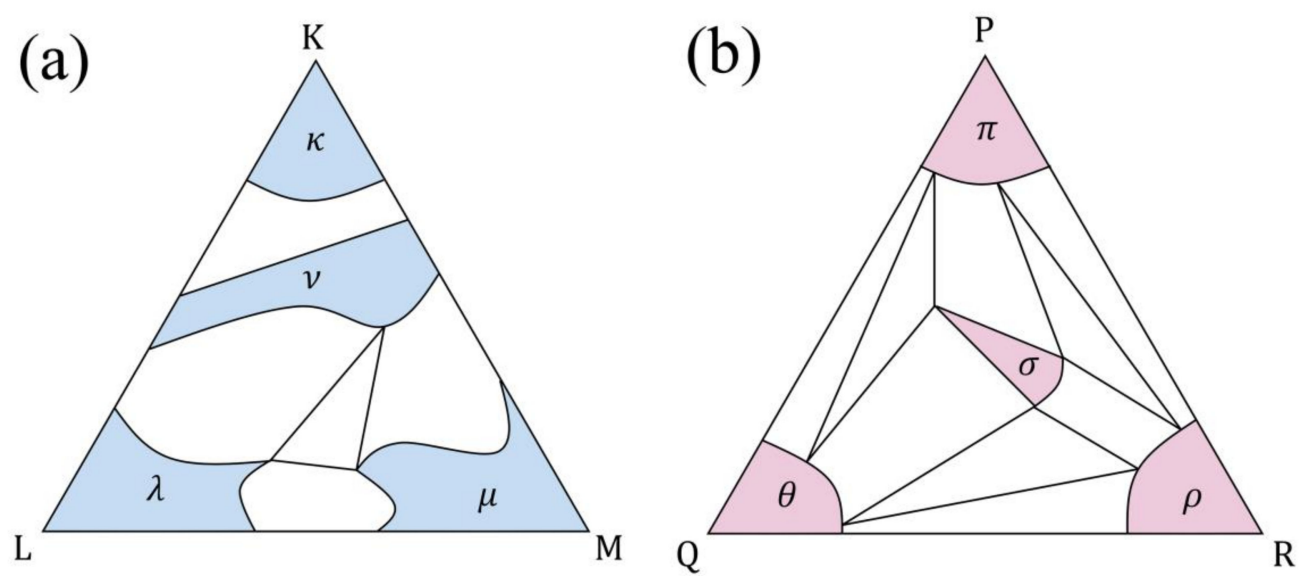

Figure 4. Imaginary phase diagrams illustrating the inheritance of IM phases in ternary systems. Colored areas represent single phase regions. (a) A phase inherited from two binary subsystems (the $v$ phase); (b) A phase that is original to the ternary systems (the $\sigma$ phase).

However, there are cases where the IM phase cannot be found in any of the binary subsystems. Therefore, the IM phase is not inherited and is original to the ternary alloy. In such cases, the phase region of the IM phase is in the interior of the phase diagram, as illustrated in Figure $4 \mathrm{~b}$. Similar situations can be seen in quaternary systems, too. For example, in the Al-Co-Fe-Ti system, the TiFeCoAl phase (cF16-LiMgPdSn) is original and does not exist in any of its binary or ternary subsystems. What about the case in HEAs? Are the IM structures in HEAs inherited from their subsystems? Do original structures exist? If so, what are they and how often do they appear?

Table 1 shows the IM structures in each HEA collected in this study. We performed a detailed analysis on these structures to identify whether or not the structure is inherited. In some trivial cases, this can be confirmed directly from the chemical formula. For example, a $\mathrm{Fe}_{2} \mathrm{Ti}$ phase in the $\mathrm{CoCrCuFeNiTi}$ alloy is clearly inherited from the Fe-Ti binary system. In other cases, this is done by comparing the structure prototypes of the IM phases in an HEA and those in its subsystems. The result is indicated in the "IM Structure Found in" column in Table 1. As shown in the table, all the IM structures in the 142 alloys can be found in the subsystems of the respective alloy. In fact, in more than $90 \%$ of the alloys (129 out of 142 alloys), the IM structures are found in binary subsystems. In the remaining 13 alloys, the structures cannot be found in binary subsystems and are seen only in ternary ones. A typical reason for this is that the structure is intrinsically ternary (i.e., three different elements are required to form that structure). This is typically reflected by a ternary prototype. The best example is the $\mathrm{L} 2{ }_{1}$ or Heusler phase ( $\left(\mathrm{FF} 16-\mathrm{AlCu}_{2} \mathrm{Mn}\right) .8$ of the 13 remaining alloys contain the $\mathrm{L} 2{ }_{1}$ phase. There are also structures that are not intrinsically ternary, but are still found in ternary subsystems only. The most notable case is the $x$ phase (found in the Cr-Fe-Ti system).

Based on the above, for all the HEAs in this study, the IM structures are inherited from their respective binary/ternary subsystems. This information has important implications. To predict the IM phases in HEAs, whether via empirical or CALPHAD approaches, a list of candidate phases is necessary 
so that the relative stabilities of the candidate phases can be compared to determine the stable phase. If the IM structures in an HEA are frequently irrelevant to its binary and ternary subsystems, given that phase diagrams of quaternary and higher-order systems are very rare, the prediction of IM phases in HEAs would be extremely difficult. Our results; however, show that the candidate IM phases basically resides in the binary and ternary subsystems, so phase prediction is feasible. Another way of looking at this is that if the composing elements in an HEA do not form a particular IM structure, it is unlikely that that phase will appear in the alloy.

Our results also suggest that when considering the candidate IM phases in an HEA, it is reasonable to consider just the phases in binary subsystems, plus certain important structures from known ternary combinations. This is because in more than $90 \%$ of the alloys, the IM phases exist in their binary subsystems. Moreover, those existing only in ternary subsystems are highly focused on certain element combinations. For example, the $\mathrm{L}_{1}$ phase is related to the Al-Ni-Ti combination, and the $x$ phase is related to the $\mathrm{Cr}$-Fe-Ti combination. Further analysis of the dependence of IM phase type on composition is underway and will be published later.

\section{Conclusions}

A database of IM-containing HEAs has been constructed by examining related publications. The database consists of 142 unique alloys. Care is taken to avoid compositional repetition so that the diversity in the database is enhanced and statistical bias is reduced. The usage of elements in these alloys is very non-uniform and highly concentrated to $\mathrm{Co}, \mathrm{Cr}, \mathrm{Fe}, \mathrm{Ni}, \mathrm{Al}$, and $\mathrm{Ti}$, all appearing in $50 \%$ or more of the alloys.

Based on statistical analysis of the database, it is found that the five most prevalent IM structures in all HEAs are Laves, $\sigma, \mathrm{B} 2, \mathrm{~L} 1_{2}$, and $\mathrm{L}_{2}$. Those in $(\mathrm{Co}, \mathrm{Cr}, \mathrm{Fe}, \mathrm{Ni})$-based HEAs are the same, but with a different sequence. These results are evidently different from the overall trend in known binary/ternary IM structures mainly because the non-uniform usage of the elements in the alloys, which prevents the formation of many structures.

All the IM structures in the HEAs surveyed here are existing structures in the binary/ternary subsystems of the respective alloys. This means that HEAs tend to inherit IM structures from their subsystems, instead of forming new structures irrelevant to their subsystems. It seems that the compositional complexity in HEAs does not trigger additional structural complexity. Therefore, when predicting IM phases in HEAs, it is probably reasonable to consider only the IM phase types existing in the binary and ternary subsystems of the alloys, and ignore irrelevant phases. These findings have important implications in the future design and development of HEAs.

Author Contributions: M.H.T. designed the research and wrote the paper. R.C.T and M.H.T. constructed the database. R.C.T, M.H.T., T.C., and W.F.H analyzed the data and did the illustrations.

Funding: This research was financially supported by the Ministry of Science and Technology, Taiwan (under grant MOST 107-2218-E-005-006) and the High Entropy Materials Center from the Featured Areas Research Center Program within the framework of the Higher Education Sprout Project by the Ministry of Education (MOE), Taiwan and from project MOST 107-3017-F-007-003 by Ministry of Science and Technology (MOST), Taiwan.

Conflicts of Interest: The authors declare no conflict of interest.

\section{References}

1. Yeh, J.W.; Chen, S.K.; Lin, S.J.; Gan, J.Y.; Chin, T.S.; Shun, T.T.; Tsau, C.H.; Chang, S.Y. Nanostructured high-entropy alloys with multiple principal elements: Novel alloy design concepts and outcomes. Adv. Eng. Mater. 2004, 6, $299-303$. [CrossRef]

2. Tsai, M.H.; Yeh, J.W. High-Entropy Alloys: A Critical Review. Mater. Res. Lett. 2014, 2, 107-123. [CrossRef]

3. Miracle, D.B.; Senkov, O.N. A critical review of high entropy alloys and related concepts. Acta Mater. 2017, 122, 448-511. [CrossRef]

4. Zhang, Y.; Zhou, Y.J.; Lin, J.P.; Chen, G.L.; Liaw, P.K. Solid-solution phase formation rules for multi-component alloys. Adv. Eng. Mater. 2008, 10, 534-538. [CrossRef] 
5. Guo, S.; Liu, C.T. Phase stability in high entropy alloys: Formation of solid-solution phase or amorphous phase. Prog. Nat. Sci. Mater. Int. 2011, 21, 433-446. [CrossRef]

6. Guo, S. Phase selection rules for cast high entropy alloys: An overview. Mater. Sci. Technol. 2015, 31, 1223-1230. [CrossRef]

7. Tsai, K.Y.; Tsai, M.H.; Yeh, J.W. Sluggish diffusion in Co-Cr-Fe-Mn-Ni high-entropy alloys. Acta Mater. 2013, 61, 4887-4897. [CrossRef]

8. Zaddach, A.J.; Niu, C.; Koch, C.C.; Irving, D.L. Mechanical Properties and Stacking Fault Energies of $\mathrm{NiFeCrCoMn} \mathrm{High-Entropy} \mathrm{Alloy.} \mathrm{JOM} \mathrm{2013,} \mathrm{65,} \mathrm{1780-1789.} \mathrm{[CrossRef]}$

9. Liu, W.H.; Wu, Y.; He, J.Y.; Nieh, T.G.; Lu, Z.P. Grain growth and the Hall-Petch relationship in a high-entropy FeCrNiCoMn alloy. Scr. Mater. 2013, 68, 526-529. [CrossRef]

10. Laplanche, G.; Gadaud, P.; Horst, O.; Otto, F.; Eggeler, G.; George, E.P. Temperature dependencies of the elastic moduli and thermal expansion coefficient of an equiatomic, single-phase CoCrFeMnNi high-entropy alloy. J. Alloys Compd. 2015, 623, 348-353. [CrossRef]

11. Laplanche, G.; Bonneville, J.; Varvenne, C.; Curtin, W.A.; George, E.P. Thermal activation parameters of plastic flow reveal deformation mechanisms in the CrMnFeCoNi high-entropy alloy. Acta Mater. 2018, 143, 257-264. [CrossRef]

12. Gludovatz, B.; Hohenwarter, A.; Catoor, D.; Chang, E.H.; George, E.P.; Ritchie, R.O. A fracture-resistant high-entropy alloy for cryogenic applications. Science 2014, 345, 1153-1158. [CrossRef] [PubMed]

13. Zhang, Y.; Stocks, G.M.; Jin, K.; Lu, C.; Bei, H.; Sales, B.C.; Wang, L.; Beland, L.K.; Stoller, R.E.; Samolyuk, G.D.; et al. Influence of chemical disorder on energy dissipation and defect evolution in concentrated solid solution alloys. Nat. Commun. 2015, 6, 8376. [CrossRef] [PubMed]

14. Zhang, Z.; Mao, M.M.; Wang, J.; Gludovatz, B.; Zhang, Z.; Mao, S.X.; George, E.P.; Yu, Q.; Ritchie, R.O. Nanoscale origins of the damage tolerance of the high-entropy alloy CrMnFeCoNi. Nat. Commun. 2015, 6, 10143. [CrossRef] [PubMed]

15. Zou, Y.; Ma, H.; Spolenak, R. Ultrastrong ductile and stable high-entropy alloys at small scales. Nat. Commun. 2015, 6, 7748. [CrossRef] [PubMed]

16. Li, Z.; Pradeep, K.G.; Deng, Y.; Raabe, D.; Tasan, C.C. Metastable high-entropy dual-phase alloys overcome the strength-ductility trade-off. Nature 2016, 534, 227-230. [CrossRef] [PubMed]

17. Gali, A.; George, E.P. Tensile properties of high- and medium-entropy alloys. Intermetallics 2013, 39, 74-78. [CrossRef]

18. Gludovatz, B.; George, E.P.; Ritchie, R.O. Processing, Microstructure and Mechanical Properties of the CrMnFeCoNi High-Entropy Alloy. JOM 2015, 67, 2262-2270. [CrossRef]

19. Miracle, D.; Miller, J.; Senkov, O.; Woodward, C.; Uchic, M.; Tiley, J. Exploration and Development of High Entropy Alloys for Structural Applications. Entropy 2014, 16, 494-525. [CrossRef]

20. Lu, Z.P.; Wang, H.; Chen, M.W.; Baker, I.; Yeh, J.W.; Liu, C.T.; Nieh, T.G. An assessment on the future development of high-entropy alloys: Summary from a recent workshop. Intermetallics 2015, 66, 67-76. [CrossRef]

21. Tsai, M.H. Three Strategies for the Design of Advanced High-Entropy Alloys. Entropy 2016, 18, 252. [CrossRef]

22. Chuang, M.H.; Tsai, M.H.; Wang, W.R.; Lin, S.J.; Yeh, J.W. Microstructure and wear behavior of $\mathrm{Al}_{\mathrm{x}} \mathrm{Co}_{1.5} \mathrm{CrFeNi}_{1.5} \mathrm{Ti}_{\mathrm{y}}$ high-entropy alloys. Acta Mater. 2011, 59, 6308-6317. [CrossRef]

23. Chuang, M.H.; Tsai, M.H.; Tsai, C.W.; Yang, N.H.; Chang, S.Y.; Yeh, J.W.; Chen, S.K.; Lin, S.J. Intrinsic surface hardening and precipitation kinetics of $\mathrm{Al}_{0.3} \mathrm{CrFe}_{1.5} \mathrm{MnNi}_{0.5}$ multi-component alloy. J. Alloys Compd. 2013, 551, 12-18. [CrossRef]

24. He, J.Y.; Wang, H.; Huang, H.L.; Xu, X.D.; Chen, M.W.; Wu, Y.; Liu, X.J.; Nieh, T.G.; An, K.; Lu, Z.P. A precipitation-hardened high-entropy alloy with outstanding tensile properties. Acta Mater. 2016, 102, 187-196. [CrossRef]

25. Liu, W.H.; Lu, Z.P.; He, J.Y.; Luan, J.H.; Wang, Z.J.; Liu, B.; Liu, Y.; Chen, M.W.; Liu, C.T. Ductile CoCrFeNiMox high entropy alloys strengthened by hard intermetallic phases. Acta Mater. 2016, 116, 332-342. [CrossRef]

26. Wani, I.S.; Bhattacharjee, T.; Sheikh, S.; Lu, Y.P.; Chatterjee, S.; Bhattacharjee, P.P.; Guo, S.; Tsuji, N. Ultrafine-grained $\mathrm{AlCoCrFeNi}{ }_{2.1}$ eutectic high-entropy alloy. Mater. Res. Lett. 2016, 4, 174-179. [CrossRef]

27. Ming, K.S.; Bi, X.F.; Wang, J. Precipitation strengthening of ductile $\mathrm{Cr}_{15} \mathrm{Fe}_{20} \mathrm{Co}_{35} \mathrm{Ni}_{20} \mathrm{Mo}_{10}$ alloys. Scr. Mater. 2017, 137, 88-93. [CrossRef] 
28. Troparevsky, M.C.; Morris, J.R.; Kent, P.R.C.; Lupini, A.R.; Stocks, G.M. Criteria for Predicting the Formation of Single-Phase High-Entropy Alloys. Phys. Rev. X 2015, 5, 011041. [CrossRef]

29. Senkov, O.N.; Miracle, D.B. A new thermodynamic parameter to predict formation of solid solution or intermetallic phases in high entropy alloys. J. Alloys Compd. 2016, 658, 603-607. [CrossRef]

30. Ye, Y.F.; Wang, Q.; Lu, J.; Liu, C.T.; Yang, Y. Design of high entropy alloys: A single-parameter thermodynamic rule. Scr. Mater. 2015, 104, 53-55. [CrossRef]

31. Tsai, M.H.; Li, J.H.; Fan, A.C.; Tsai, P.H. Incorrect predictions of simple solid solution high entropy alloys: Cause and possible solution. Scr. Mater. 2017, 127, 6-9. [CrossRef]

32. Tsai, M.H.; Fan, A.C.; Wang, H.A. Effect of atomic size difference on the type of major intermetallic phase in arc-melted CoCrFeNiX high-entropy alloys. J. Alloys Compd. 2017, 695, 1479-1487. [CrossRef]

33. Tsai, M.H.; Tsai, K.Y.; Tsai, C.W.; Lee, C.; Juan, C.C.; Yeh, J.W. Criterion for sigma phase formation in Cr- and V-containing high-entropy alloys. Mater. Res. Lett. 2013, 1, 207-212. [CrossRef]

34. Tsai, M.H.; Chang, K.C.; Li, J.H.; Tsai, R.C.; Cheng, A.H. A second criterion for sigma phase formation in high-entropy alloys. Mater. Res. Lett. 2016, 4, 90-95. [CrossRef]

35. Yurchenko, N.; Stepanov, N.; Salishchev, G. Laves-phase formation criterion for high-entropy alloys. J. Energy Mater. 2016, 11, 17-22. [CrossRef]

36. Villars, P.; Calvert, L.D. (Eds.) Pearson's Handbook of Crystallographic Data for Intermetallic Phases, 2nd ed.; ASM International: Materials Park, OH, USA, 1991.

37. He, J.Y.; Liu, W.H.; Wang, H.; Wu, Y.; Liu, X.J.; Nieh, T.G.; Lu, Z.P. Effects of Al addition on structural evolution and tensile properties of the FeCoNiCrMn high-entropy alloy system. Acta Mater. 2014, 62, 105-113. [CrossRef]

38. Ferro, P.; Saccone, A. Structure of Intermetallic Compounds and Phases. In Physical Metallurgy, 4th ed.; Cahn, R.W., Haasen, P., Eds.; Elsevier Science B.V.: Amsterdam, The Netherlands, 1996; Volume 1, pp. 206-369.

39. Villars, P.; Prince, A.; Okamoto, H. Handbook of Ternary Alloy Phase Diagrams; ASM International: Materials Park, OH, USA, 1995; Volume 3.

40. Baker, H. (Ed.) ASM Handbook: Alloy Phase Diagrams; ASM International: Materials Park, OH, USA, 1992.

41. Villars, P.; Cenzual, K.; Gladyshevskii, R. Handbook of Inorganic Substances 2015; De Gruyter: Berlin, Germany, 2015.

42. Zhou, Y.; Zhang, Y.; Wang, Y.; Chen, G. Solid solution alloys of AlCoCrFeNiTi $\mathrm{Al}_{x}$ with excellent room-temperature mechanical properties. Appl. Phys. Lett. 2007, 90, 181904. [CrossRef]

43. Wu, C.; Zhang, S.; Zhang, C.; Zhang, H.; Dong, S. Phase evolution and cavitation erosion-corrosion behavior of FeCoCrAlNiTi $x$ high entropy alloy coatings on 304 stainless steel by laser surface alloying. J. Alloys Compd. 2017, 698, 761-770. [CrossRef]

44. Gwalani, B.; Soni, V.; Choudhuri, D.; Lee, M.; Hwang, J.; Nam, S.; Ryu, H.; Hong, S.; Banerjee, R. Stability of ordered $\mathrm{L}_{2}$ and $\mathrm{B} 2$ precipitates in face centered cubic based high entropy alloys-Al0.3CoFeCrNi and Al0.3CuFeCrNi2. Scr. Mater. 2016, 123, 130-134. [CrossRef]

45. Hsu, U.S.; Hung, U.D.; Yeh, J.W.; Chen, S.K.; Huang, Y.S.; Yang, C.C. Alloying behavior of iron, gold and silver in AlCoCrCuNi-based equimolar high-entropy alloys. Mater. Sci. Eng. A 2007, 460, 403-408. [CrossRef]

46. Lee, C.; Chen, Y.; Hsu, C.; Yeh, J.; Shih, H. Effect of Boron on the Corrosion Properties of Al0.5CoCrCuFeNiBx High Entropy Alloys in 1N Sulfuric Acid. In Proceedings of the 209th Electrochemical Society (ECS) Meeting, Denver, CO, USA, 7-12 May 2006.

47. Zhang, H.; He, Y.; Pan, Y. Enhanced hardness and fracture toughness of the laser-solidified FeCoNiCrCuTiMoAlSiB0.5 high-entropy alloy by martensite strengthening. Scr. Mater. 2013, 69, 342-345. [CrossRef]

48. Shun, T.-T.; Du, Y.-C. Age hardening of the Al0.3CoCrFeNiC0.1 high entropy alloy. J. Alloys Compd. 2009, 478, 269-272. [CrossRef]

49. Fang, S.; Chen, W.; Fu, Z. Microstructure and mechanical properties of twinned A10.5CrFeNiCo0.3C0.2 high entropy alloy processed by mechanical alloying and spark plasma sintering. Mater. Des. (1980-2015) 2014, 54, 973-979. [CrossRef]

50. Praveen, S.; Murty, B.S.; Kottada, R.S. Alloying behavior in multi-component AlCoCrCuFe and NiCoCrCuFe high entropy alloys. Mater. Sci. Eng. A 2012, 534, 83-89. [CrossRef]

51. Zhou, Y.J.; Zhang, Y.; Wang, Y.L.; Chen, G.L. Microstructure and compressive properties of multicomponent $\mathrm{Al}_{x}(\mathrm{TiVCrMnFeCoNiCu})_{100-\mathrm{x}}$ high-entropy alloys. Mater. Sci. Eng. A 2007, 454-455, 260-265. [CrossRef] 
52. Yuhu, F.; Yunpeng, Z.; Hongyan, G.; Huimin, S.; Li, H. AlNiCrFexMo0.2CoCu High Entropy Alloys Prepared by Powder Metallurgy. Rare Met. Mater. Eng. 2013, 42, 1127-1129. [CrossRef]

53. Manzoni, A.M.; Daoud, H.M.; Voelkl, R.; Glatzel, U.; Wanderka, N. Influence of W, Mo and Ti trace elements on the phase separation in Al8Co17Cr17Cu8Fe17Ni33 based high entropy alloy. Ultramicroscopy 2015, 159 Pt 2, 265-271. [CrossRef]

54. Ng, C.; Guo, S.; Luan, J.; Shi, S.; Liu, C.T. Entropy-driven phase stability and slow diffusion kinetics in an $\mathrm{Al}_{0.5} \mathrm{CoCrCuFeNi}$ high entropy alloy. Intermetallics 2012, 31, 165-172. [CrossRef]

55. Singh, S.; Wanderka, N.; Murty, B.S.; Glatzel, U.; Banhart, J. Decomposition in multi-component AlCoCrCuFeNi high-entropy alloy. Acta Mater. 2011, 59, 182-190. [CrossRef]

56. Jensen, J.; Welk, B.; Williams, R.; Sosa, J.; Huber, D.; Senkov, O.; Viswanathan, G.; Fraser, H. Characterization of the microstructure of the compositionally complex alloy Al1Mo0.5Nb1Ta0.5Ti1Zr1. Scr. Mater. 2016, 121, 1-4. [CrossRef]

57. Chen, M.-R.; Lin, S.-J.; Yeh, J.-W.; Chen, S.-K.; Huang, Y.-S.; Tu, C.-P. Microstructure and Properties of $\mathrm{Al}_{0.5} \mathrm{CoCrCuFeNiTi}_{x}(\mathrm{x}=0$-2.0) High-Entropy Alloys. Jpn. Inst. Met. 2006, 47, 1395-1401.

58. Chen, M.-R.; Lin, S.-J.; Yeh, J.-W.; Chuang, M.-H.; Chen, S.-K.; Huang, Y.-S. Effect of vanadium addition on the microstructure, hardness, and wear resistance of Al0.5CoCrCuFeNi high-entropy alloy. Metall. Mater. Trans. A-Phys. Metall. Mater. Sci. 2006, 37, 1363-1369. [CrossRef]

59. Young, K.; Ouchi, T.; Huang, B.; Reichman, B.; Fetcenko, M.A. Studies of copper as a modifier in C14-predominant AB2 metal hydride alloys. J. Power Sources 2012, 204, 205-212. [CrossRef]

60. Wang, Z.; Wang, X.; Yue, H.; Shi, G.; Wang, S. Microstructure, thermodynamics and compressive properties of AlCoCrCuMn-x (x=Fe, Ti) high-entropy alloys. Mater. Sci. Eng. A 2015, 627, 391-398. [CrossRef]

61. Yeh, J.W.; Lin, S.J.; Chin, T.S.; Gan, J.Y.; Chen, S.K.; Shun, T.T.; Tsau, C.H.; Chou, S.Y. Formation of simple crystal structures in Cu-Co-Ni-Cr-Al-Fe-Ti-V alloys with multiprincipal metallic elements. Metall. Mater. Trans. A 2004, 35, 2533-2536. [CrossRef]

62. Hu, Z.; Zhan, Y.; Zhang, G.; She, J.; Li, C. Effect of rare earth Y addition on the microstructure and mechanical properties of high entropy AlCoCrCuNiTi alloys. Mater. Des. 2010, 31, 1599-1602. [CrossRef]

63. Juan, C.C.; Hsu, C.Y.; Tsai, C.W.; Wang, W.R.; Sheu, T.S.; Yeh, J.W.; Chen, S.K. On microstructure and mechanical performance of AlCoCrFeMo0.5Nix high-entropy alloys. Intermetallics 2013, 32, 401-407. [CrossRef]

64. Ma, S.; Zhang, Y. Effect of $\mathrm{Nb}$ addition on the microstructure and properties of $\mathrm{AlCoCrFeNi}$ high-entropy alloy. Mater. Sci. Eng. A 2012, 532, 480-486. [CrossRef]

65. Zhang, H.; He, Y.-Z.; Pan, Y.; Pei, L.-Z. Phase selection, microstructure and properties of laser rapidly solidified FeCoNiCrAl2Si coating. Intermetallics 2011, 19, 1130-1135. [CrossRef]

66. Wang, L.; Chen, C.; Yeh, J.; Ke, S. The microstructure and strengthening mechanism of thermal spray coating NixCo0.6Fe0.2CrySizAlTi0.2 high-entropy alloys. Mater. Chem. Phys. 2011, 126, 880-885. [CrossRef]

67. Lee, C.-F.; Shun, T.-T. Effect of Fe content on microstructure and mechanical properties of $\mathrm{Al}_{0.5} \mathrm{CoCrFe}_{x} \mathrm{NiTi}_{0.5}$ high-entropy alloys. Mater. Charact. 2016, 114, 179-184. [CrossRef]

68. Zhang, K.; Fu, Z.; Zhang, J.; Wang, W.; Wang, H.; Wang, Y.; Zhang, Q.; Shi, J. Microstructure and mechanical properties of CoCrFeNiTiAl $x$ high-entropy alloys. Mater. Sci. Eng. A 2009, 508, 214-219. [CrossRef]

69. Chen, J.; Niu, P.; Liu, Y.; Lu, Y.; Wang, X.; Peng, Y.; Liu, J. Effect of Zr content on microstructure and mechanical properties of AlCoCrFeNi high entropy alloy. Mater. Des. 2016, 94, 39-44. [CrossRef]

70. Lee, C.-F.; Shun, T.-T. Age hardening of the Al0.5CoCrNiTi0.5 high-entropy alloy. Metall. Mater. Trans. A-Phys. Metall. Mater. Sci. 2014, 45, 191-195. [CrossRef]

71. Liu, L.; He, L.; Qi, J.; Wang, B.; Zhao, Z.; Shang, J.; Zhang, Y. Effects of Sn element on microstructure and properties of SnxAl2.5FeCoNiCu multi-component alloys. J. Alloys Compd. 2016, 654, 327-332. [CrossRef]

72. Liu, L.; Zhu, J.; Hou, C.; Li, J.; Jiang, Q. Dense and smooth amorphous films of multicomponent FeCoNiCuVZrAl high-entropy alloy deposited by direct current magnetron sputtering. Mater. Des. 2013, 46, 675-679. [CrossRef]

73. Zhuang, Y.; Liu, W.; Chen, Z.; Xue, H.; He, J. Effect of elemental interaction on microstructure and mechanical properties of FeCoNiCuAl alloys. Mater. Sci. Eng. A 2012, 556, 395-399. [CrossRef]

74. Mohanty, S.; Gurao, N.; Biswas, K. Sinter ageing of equiatomic Al20Co20Cu20Zn20Ni20 high entropy alloy via mechanical alloying. Mater. Sci. Eng. A 2014, 617, 211-218. [CrossRef] 
75. Hsu, C.-Y.; Juan, C.-C.; Wang, W.-R.; Sheu, T.-S.; Yeh, J.-W.; Chen, S.-K. On the superior hot hardness and softening resistance of $\mathrm{AlCoCr}_{x} \mathrm{FeMo0.5}$ Ni high-entropy alloys. Mater. Sci. Eng. A 2011, 528, 3581-3588. [CrossRef]

76. Butler, T.; Alfano, J.; Martens, R.; Weaver, M. High-temperature oxidation behavior of Al-Co-Cr-Ni-(Fe or Si) multicomponent high-entropy alloys. JOM 2015, 67, 246-259. [CrossRef]

77. Maulik, O.; Kumar, D.; Kumar, S.; Fabijanic, D.M.; Kumar, V. Structural evolution of spark plasma sintered $\mathrm{AlFeCuCrMg} x(\mathrm{x}=0,0.5,1,1.7)$ high entropy alloys. Intermetallics 2016, 77, 46-56. [CrossRef]

78. Khanchandani, H.; Sharma, P.; Kumar, R.; Maulik, O.; Kumar, V. Effect of sintering on phase evolution in AlMgFeCuCrNi4.75 high entropy alloy. Adv. Powder Technol. 2016, 27, 289-294. [CrossRef]

79. Guo, S.; Ng, C.; Liu, C.T. Anomalous solidification microstructures in Co-free AlxCrCuFeNi2 high-entropy alloys. J. Alloys Compd. 2013, 557, 77-81. [CrossRef]

80. Choudhuri, D.; Gwalani, B.; Gorsse, S.; Mikler, C.; Ramanujan, R.; Gibson, M.; Banerjee, R. Change in the primary solidification phase from fcc to bcc-based B2 in high entropy or complex concentrated alloys. Scr. Mater. 2017, 127, 186-190. [CrossRef]

81. Pi, J.-H.; Pan, Y.; Zhang, L.; Zhang, H. Microstructure and property of AlTiCrFeNiCu high-entropy alloy. J. Alloys Compd. 2011, 509, 5641-5645. [CrossRef]

82. Baker, I.; Meng, F.; Wu, M.; Brandenberg, A. Recrystallization of a novel two-phase FeNiMnAlCr high entropy alloy. J. Alloys Compd. 2016, 656, 458-464. [CrossRef]

83. Tsai, M.-H.; Yuan, H.; Cheng, G.; Xu, W.; Jian, W.W.; Chuang, M.-H.; Juan, C.-C.; Yeh, A.-C.; Lin, S.-J.; Zhu, Y. Significant hardening due to the formation of a sigma phase matrix in a high entropy alloy. Intermetallics 2013, 33, 81-86. [CrossRef]

84. Dong, Y.; Gao, X.; Lu, Y.; Wang, T.; Li, T. A multi-component AlCrFe2Ni2 alloy with excellent mechanical properties. Mater. Lett. 2016, 169, 62-64. [CrossRef]

85. Dong, Y.; Lu, Y.; Kong, J.; Zhang, J.; Li, T. Microstructure and mechanical properties of multi-component AlCrFeNiMox high-entropy alloys. J. Alloys Compd. 2013, 573, 96-101. [CrossRef]

86. Lin, C.W.; Tsai, M.H.; Tsai, C.W.; Yeh, J.W.; Chen, S.K. Microstructure and aging behaviour of Al5Cr32Fe35Ni22Ti6 high entropy alloy. Mater. Sci. Technol. 2015, 31, 1165-1170. [CrossRef]

87. Young, K.; Regmi, R.; Lawes, G.; Ouchi, T.; Reichman, B.; Fetcenko, M.; Wu, A. Effects of aluminum substitution in C14-rich multi-component alloys for NiMH battery application. J. Alloys Compd. 2010, 490, 282-292. [CrossRef]

88. Chen, H.; Kauffmann, A.; Gorr, B.; Schliephake, D.; Seemüller, C.; Wagner, J.; Christ, H.-J.; Heilmaier, M. Microstructure and mechanical properties at elevated temperatures of a new Al-containing refractory high-entropy alloy Nb-Mo-Cr-Ti-Al. J. Alloys Compd. 2016, 661, 206-215. [CrossRef]

89. Chang, H.-W.; Huang, P.-K.; Davison, A.; Yeh, J.-W.; Tsau, C.-H.; Yang, C.-C. Nitride films deposited from an equimolar $\mathrm{Al}-\mathrm{Cr}-\mathrm{Mo}-\mathrm{Si}-\mathrm{Ti}$ alloy target by reactive direct current magnetron sputtering. Thin Solid Films 2008, 516, 6402-6408. [CrossRef]

90. Stepanov, N.; Yurchenko, N.Y.; Panina, E.; Tikhonovsky, M.; Zherebtsov, S. Precipitation-strengthened refractory Al0.5CrNbTi2V0.5 high entropy alloy. Mater. Lett. 2017, 188, 162-164. [CrossRef]

91. Yurchenko, N.Y.; Stepanov, N.; Shaysultanov, D.; Tikhonovsky, M.; Salishchev, G. Effect of Al content on structure and mechanical properties of the $\mathrm{Al} x \mathrm{CrNbTiVZr}(\mathrm{x}=0 ; 0.25 ; 0.5 ; 1)$ high-entropy alloys. Mater. Charact. 2016, 121, 125-134. [CrossRef]

92. Huang, C.; Zhang, Y.; Shen, J.; Vilar, R. Thermal stability and oxidation resistance of laser clad TiVCrAlSi high entropy alloy coatings on Ti-6Al-4V alloy. Surf. Coat. Technol. 2011, 206, 1389-1395. [CrossRef]

93. Yang, X.; Chen, S.; Cotton, J.; Zhang, Y. Phase stability of low-density, multiprincipal component alloys containing aluminum, magnesium, and lithium. JOM 2014, 66, 2009-2020. [CrossRef]

94. Zhang, Z.; Axinte, E.; Ge, W.; Shang, C.; Wang, Y. Microstructure, mechanical properties and corrosion resistance of CuZrY/Al, Ti, Hf series high-entropy alloys. Mater. Des. 2016, 108, 106-113. [CrossRef]

95. Wang, Z.; Wu, M.; Cai, Z.; Chen, S.; Baker, I. Effect of Ti content on the microstructure and mechanical behavior of $\left(\mathrm{Fe}_{36} \mathrm{Ni}_{18} \mathrm{Mn}_{33} \mathrm{Al}_{13}\right)_{100-x} \mathrm{Ti}_{x}$ high entropy alloys. Intermetallics 2016, 75, 79-87. [CrossRef]

96. Poletti, M.; Branz, S.; Fiore, G.; Szost, B.; Crichton, W.; Battezzati, L. Equilibrium high entropy phases in X-NbTaTiZr (X= Al, V, Cr and Sn) multiprincipal component alloys. J. Alloys Compd. 2016, 655, 138-146. [CrossRef] 
97. Tan, X.-R.; Zhang, G.-P.; Zhi, Q.; Liu, Z.-X. Effects of milling on the microstructure and hardness of Al2NbTi3V2Zr high-entropy alloy. Mater. Des. 2016, 109, 27-36. [CrossRef]

98. Yurchenko, N.Y.; Stepanov, N.D.; Tikhonovsky, M.A.; Salishchev, G.A. Phase Evolution of the Al $x \mathrm{NbTiVZr}$ (x=0; 0.5; 1; 1.5) High Entropy Alloys. Metals 2016, 6, 298. [CrossRef]

99. Ding, J.; Inoue, A.; Han, Y.; Kong, F.; Zhu, S.; Wang, Z.; Shalaan, E.; Al-Marzouki, F. High entropy effect on structure and properties of (Fe, Co, Ni, Cr)-B amorphous alloys. J. Alloys Compd. 2017, 696, 345-352. [CrossRef]

100. Stepanov, N.; Yurchenko, N.Y.; Tikhonovsky, M.; Salishchev, G. Effect of carbon content and annealing on structure and hardness of the CoCrFeNiMn-based high entropy alloys. J. Alloys Compd. 2016, 687, 59-71. [CrossRef]

101. Guo, N.; Wang, L.; Luo, L.; Li, X.; Chen, R.; Su, Y.; Guo, J.; Fu, H. Microstructure and mechanical properties of in-situ MC-carbide particulates-reinforced refractory high-entropy Mo0.5NbHf0.5ZrTi matrix alloy composite. Intermetallics 2016, 69, 74-77. [CrossRef]

102. Wang, X.; Zhang, Y.; Qiao, Y.; Chen, G. Novel microstructure and properties of multicomponent CoCrCuFeNiTi $x$ alloys. Intermetallics 2007, 15, 357-362. [CrossRef]

103. Guo, S.; Hu, Q.; Ng, C.; Liu, C. More than entropy in high-entropy alloys: Forming solid solutions or amorphous phase. Intermetallics 2013, 41, 96-103. [CrossRef]

104. Huo, W.-Y.; Shi, H.-F.; Ren, X.; Zhang, J.-Y. Microstructure and wear behavior of CoCrFeMnNbNi high-entropy alloy coating by TIG cladding. Adv. Mater. Sci. Eng. 2015, 2015, 647351. [CrossRef]

105. Stepanov, N.; Shaysultanov, D.; Salishchev, G.; Tikhonovsky, M.; Oleynik, E.; Tortika, A.; Senkov, O. Effect of $\mathrm{V}$ content on microstructure and mechanical properties of the $\mathrm{CoCrFeMnNiV}_{x}$ high entropy alloys. J. Alloys Compd. 2015, 628, 170-185. [CrossRef]

106. Shun, T.-T.; Chang, L.-Y.; Shiu, M.-H. Microstructure and mechanical properties of multiprincipal component CoCrFeNiMo $x$ alloys. Mater. Charact. 2012, 70, 63-67. [CrossRef]

107. Shun, T.T.; Chang, L.Y.; Shiu, M.H. Age-hardening of the CoCrFeNiMo0.85 high-entropy alloy. Mater. Charact. 2013, 81, 92-96. [CrossRef]

108. Chou, Y.; Yeh, J.; Shih, H. The effect of molybdenum on the corrosion behaviour of the high-entropy alloys Co1.5CrFeNi1.5Ti0.5Mox in aqueous environments. Corros. Sci. 2010, 52, 2571-2581. [CrossRef]

109. Liu, W.; He, J.; Huang, H.; Wang, H.; Lu, Z.; Liu, C. Effects of Nb additions on the microstructure and mechanical property of CoCrFeNi high-entropy alloys. Intermetallics 2015, 60, 1-8. [CrossRef]

110. Shun, T.-T.; Hung, C.-H.; Lee, C.-F. Formation of ordered/disordered nanoparticles in FCC high entropy alloys. J. Alloys Compd. 2010, 493, 105-109. [CrossRef]

111. Shun, T.T.; Chang, L.Y.; Shiu, M.-H. Microstructures and mechanical properties of multiprincipal component CoCrFeNiTi $_{x}$ alloys. Mater. Sci. Eng. A 2012, 556, 170-174. [CrossRef]

112. Jiang, L.; Lu, Y.; Dong, Y.; Wang, T.; Cao, Z.; Li, T. Annealing effects on the microstructure and properties of bulk high-entropy CoCrFeNiTi 0.5 alloy casting ingot. Intermetallics 2014, 44, 37-43. [CrossRef]

113. Zhang, K.; Fu, Z. Effects of annealing treatment on phase composition and microstructure of $\mathrm{CoCrFeNiTiAl}_{x}$ high-entropy alloys. Intermetallics 2012, 22, 24-32. [CrossRef]

114. Otto, F.; Yang, Y.; Bei, H.; George, E.P. Relative effects of enthalpy and entropy on the phase stability of equiatomic high-entropy alloys. Acta Mater. 2013, 61, 2628-2638. [CrossRef]

115. Cai, Z.; Jin, G.; Cui, X.; Li, Y.; Fan, Y.; Song, J. Experimental and simulated data about microstructure and phase composition of a NiCrCoTiV high-entropy alloy prepared by vacuum hot-pressing sintering. Vacuum 2016, 124, 5-10. [CrossRef]

116. Liu, L.; Zhu, J.; Zhang, C.; Li, J.; Jiang, Q. Microstructure and the properties of FeCoCuNiSn high entropy alloys. Mater. Sci. Eng. A 2012, 548, 64-68. [CrossRef]

117. Samal, S.; Rahul, M.; Kottada, R.S.; Phanikumar, G. Hot deformation behaviour and processing map of Co-Cu-Fe-Ni-Ti eutectic high entropy alloy. Mater. Sci. Eng. A 2016, 664, 227-235. [CrossRef]

118. Kao, Y.-F.; Chen, S.-K.; Sheu, J.-H.; Lin, J.-T.; Lin, W.-E.; Yeh, J.-W.; Lin, S.-J.; Liou, T.-H.; Wang, C.-W. Hydrogen storage properties of multi-principal-component $\mathrm{CoFeMnTi} x \mathrm{VyZrz}_{\mathrm{Z}}$ alloys. Int. J. Hydrogen Energy 2010, 35, 9046-9059. [CrossRef]

119. Jiang, L.; Cao, Z.; Jie, J.; Zhang, J.; Lu, Y.; Wang, T.; Li, T. Effect of Mo and Ni elements on microstructure evolution and mechanical properties of the $\mathrm{CoFeNi}_{x} \mathrm{VMo}_{\mathrm{y}}$ high entropy alloys. J. Alloys Compd. 2015, 649, 585-590. [CrossRef] 
120. Jiang, L.; Lu, Y.; Wu, W.; Cao, Z.; Li, T. Microstructure and Mechanical Properties of a CoFeNi2V0.5Nb0.75 Eutectic High Entropy Alloy in As-cast and Heat-treated Conditions. J. Mater. Sci. Technol. 2016, 32, 245-250. [CrossRef]

121. Zuo, T.; Li, R.; Ren, X.; Zhang, Y. Effects of $\mathrm{Al}$ and Si addition on the structure and properties of CoFeNi equal atomic ratio alloy. J. Magn. Magn. Mater. 2014, 371, 60-68. [CrossRef]

122. Han, Z.; Liu, X.; Zhao, S.; Shao, Y.; Li, J.; Yao, K. Microstructure, phase stability and mechanical properties of $\mathrm{Nb}-\mathrm{Ni}-\mathrm{Ti}-\mathrm{Co}-\mathrm{Zr}$ and $\mathrm{Nb}-\mathrm{Ni}-\mathrm{Ti}-\mathrm{Co}-\mathrm{Zr}-\mathrm{Hf}$ high entropy alloys. Prog. Nat. Sci. Mater. Int. 2015, 25, 365-369. [CrossRef]

123. Jiang, H.; Zhang, H.; Huang, T.; Lu, Y.; Wang, T.; Li, T. Microstructures and mechanical properties of Co2MoxNi2VWx eutectic high entropy alloys. Mater. Des. 2016, 109, 539-546. [CrossRef]

124. Lee, C.; Chang, C.; Chen, Y.; Yeh, J.; Shih, H. Effect of the aluminium content of AlxCrFe1.5MnNi0.5 high-entropy alloys on the corrosion behaviour in aqueous environments. Corros. Sci. 2008, 50, 2053-2060. [CrossRef]

125. Kunce, I.; Polanski, M.; Bystrzycki, J. Structure and hydrogen storage properties of a high entropy ZrTiVCrFeNi alloy synthesized using Laser Engineered Net Shaping (LENS). Int. J. Hydrogen Energy 2013, 38, 12180-12189. [CrossRef]

126. Jiang, H.; Jiang, L.; Han, K.; Lu, Y.; Wang, T.; Cao, Z.; Li, T. Effects of tungsten on microstructure and mechanical properties of $\mathrm{CrFeNiV}_{0.5} \mathrm{~W}_{x}$ and $\mathrm{CrFeNi}_{2} \mathrm{~V}_{0.5} \mathrm{~W}_{x}$ high-entropy alloys. J. Mater. Eng. Perform. 2015, 24, 4594-4600. [CrossRef]

127. Fazakas, E.; Zadorozhnyy, V.; Varga, L.; Inoue, A.; Louzguine-Luzgin, D.; Tian, F.; Vitos, L. Experimental and theoretical study of $\mathrm{Ti}_{20} \mathrm{Zr}_{20} \mathrm{Hf}_{20} \mathrm{Nb}_{20} \mathrm{X}_{20}(\mathrm{X}=\mathrm{V}$ or $\mathrm{Cr}$ ) refractory high-entropy alloys. Int. J. Refract. Met. Hard Mater. 2014, 47, 131-138. [CrossRef]

128. Senkov, O.; Woodward, C. Microstructure and properties of a refractory NbCrMo0.5Ta0.5TiZr alloy. Mater. Sci. Eng. A 2011, 529, 311-320. [CrossRef]

129. Senkov, O.; Senkova, S.; Woodward, C.; Miracle, D. Low-density, refractory multi-principal element alloys of the $\mathrm{Cr}-\mathrm{Nb}-\mathrm{Ti}-\mathrm{V}-\mathrm{Zr}$ system: Microstructure and phase analysis. Acta Mater. 2013, 61, 1545-1557. [CrossRef]

130. Takeuchi, A.; Wada, T.; Zhang, Y. MnFeNiCuPt and MnFeNiCuCo high-entropy alloys designed based on L1 0 structure in Pettifor map for binary compounds. Intermetallics 2017, 82, 107-115. [CrossRef]

131. Guo, N.; Wang, L.; Luo, L.; Li, X.; Chen, R.; Su, Y.; Guo, J.; Fu, H. Microstructure and mechanical properties of refractory high entropy (Mo0.5NbHf0.5ZrTi)BCC/M5Si3 in-situ compound. J. Alloys Compd. 2016, 660, 197-203. [CrossRef]

132. Zhang, Y.; Liu, Y.; Li, Y.; Chen, X.; Zhang, H. Microstructure and mechanical properties of a refractory HfNbTiVSi0.5 high-entropy alloy composite. Mater. Lett. 2016, 174, 82-85. [CrossRef]

133. Wu, Y.; Cai, Y.; Chen, X.; Wang, T.; Si, J.; Wang, L.; Wang, Y.; Hui, X. Phase composition and solid solution strengthening effect in TiZrNbMoV high-entropy alloys. Mater. Des. 2015, 83, 651-660. [CrossRef]

134. Anzorena, M.S.; Bertolo, A.; Gagetti, L.; Kreiner, A.; Mosca, H.; Bozzolo, G.; del Grosso, M. Characterization and modeling of a MoTaVWZr high entropy alloy. Mater. Des. 2016, 111, 382-388. [CrossRef]

(c) 2019 by the authors. Licensee MDPI, Basel, Switzerland. This article is an open access article distributed under the terms and conditions of the Creative Commons Attribution (CC BY) license (http://creativecommons.org/licenses/by/4.0/). 